\title{
Immunohistochemical assessment of progesterone, oestrogen and glucocorticoid receptors in bovine placentomes during pregnancy, induced parturition, and after birth with or without retention of fetal membranes
}

\author{
A. Boos ${ }^{1}$, J. Kohtes ${ }^{1}$, A. Stelljes ${ }^{1}$, H. Zerbe ${ }^{2}$ and H. H. Thole ${ }^{3}$ \\ ${ }^{1}$ Institute of Anatomy, School of Veterinary Medicine Hannover, Bischofsholer Damm 15, D-30173 Hannover, Germany; \\ ${ }^{2}$ Clinic for Bovine Obstetrics and Gynaecology, School of Veterinary Medicine Hannover, Bischofsholer Damm 15, D-30173 Hannover, \\ Germany; and ${ }^{3}$ Department of Paediatrics, Paediatric Pneumology and Neonatology, Hannover Medical School, Carl-Neuberg-Str. 1, \\ D-30623 Hannover, Germany
}

\begin{abstract}
Steroid hormones play an important role in placental development. However, the exact cellular site of hormone action has not been evaluated in bovine placentomes. Thus, the present immunohistochemical study was designed to assess the distribution of progesterone receptors, oestrogen receptors and glucocorticoid receptors in bovine placentomes. Tissue specimens were obtained from cows at slaughter and from cattle during pre-term Caesarean section $27 \mathrm{~h}$ after prostaglandin administration, immediately after spontaneous parturition and from cattle that had retained the fetal membranes. Specific antibodies were used for receptor demonstration in tissue sections. Progesterone receptors were only detected in maternal connective tissue cells, whereas oestrogen receptors were also present in maternal crypt epithelium. At specific sites, both receptor immunoreactivities remained constant or changed significantly during pregnancy, were generally higher during Caesarean section and decreased post partum, but were less pronounced in cattle that released the fetal membranes than in those that retained the fetal membranes. Glucocorticoid receptors were evident in fetal connective tissue cells as well as in fetal and maternal blood vessels. Maternal crypt epithelial cells showed increasing immunoreactivities for glucocorticoid receptors during pregnancy. Receptor immunoreactivities tended to be lower after spontaneous parturition than during Caesarean section; these results were significant for progesterone and oestrogen receptors in animals that released the fetal membranes but not for those that retained the fetal membranes. The results indicate that in bovine placentome steroid hormone receptors are distributed in patterns that are specific to the type of cell, the stage of pregnancy and the tissue location, implying highly specific modulation of placental metabolism. Retention of the fetal membranes is reflected by altered placental receptor states at parturition.
\end{abstract}

\section{Introduction}

It is well documented that the bovine uterus is a target organ for ovarian steroid hormones. In most species, corresponding receptors are expressed in two forms (oestrogen receptors $\alpha$ and $\beta$, progesterone receptors $A$ and $B$, and glucocorticoid receptors I and II) and in cattle these receptors have been isolated and sequenced totally or partially (Lauer and Einspanier, 1997; Rosenfeld et al., 1999; Walther et al., 1999). The respective receptor concentrations vary considerably during the oestrous cycle (Meyer et al., 1988; Vesanen et al., 1991) and immunohistochemical studies revealed that the distribution of these proteins in cattle is specific to the type of

Revised manuscript received 26 April 2000. cell and the tissue location (Boos et al., 1996). However, little is known about the endocrine control in bovine placentomes during pregnancy, at parturition and post partum. According to Sauerwein et al. (1989), the maternal compartment of mature bovine placentomes collected immediately after the expulsion of the fetus contains low concentrations of oestrogen receptors, whereas oestrogen receptors were not detected in the fetal compartment. Immunohistochemistry failed to detect oestrogen receptors before day 260 of pregnancy (Schoon and Schoon, 1991). Thereafter, increasing concentrations of oestrogen receptors were observed within the nuclei of caruncular stromal cells. Oestrogen receptors were not observed $24 \mathrm{~h}$ after parturition. Progesterone receptors have been localized in maternal stromal cells during mid-pregnancy and late pregnancy and at parturition 
(Schuler et al., 1999). Fetal glucocorticoids are the physiological agents for initiation of parturition in cattle and some other species (Thorburn and Liggins, 1994; Lye, 1996) and may therefore be used to induce labour (Aurich and Aurich, 1994; Hoffmann, 1994; Lye, 1996). However, to date, studies of corresponding receptors have not been performed in cattle.

Fetal membranes are expelled within 6-12 h after the delivery of the fetus (Grunert, 1983). Retention of fetal membranes is a major problem in cattle breeding as it is often followed by depressed fertility, which may result in economic loss or even culling of the animal (Laven and Peters, 1996; Gröhn et al., 1998). Although the results of extensive studies are available, the aetiology and pathogenesis of this problem are not completely understood. The role of endocrine changes in retention of the fetal membranes is a matter of controversy. Some studies indicate that hormonal patterns of animals that have retained the fetal membranes are significantly different from those in cattle that have released the fetal membranes, whereas other studies did not detect any differences (Agthe and Kolm, 1975; Chew et al., 1979; Matton et al., 1979; Elecko et al., 1982; Lotthammer, 1983; Inaba et al., 1986; Peter and Bosu, 1987; Grunert et al., 1989; Fürstenberg et al., 1990; Kankofer et al., 1996; Zhang et al., 1999). Immunohistochemical methods demonstrated that oestrogen receptors are present for a longer period of time in the nuclei of caruncular stromal cells of animals that retain the fetal membranes than in animals that release the fetal membranes (Schoon and Schoon, 1991).

In the present study, immunohistochemical methods were used to investigate the presence and distribution of progesterone receptors, oestrogen receptors and glucocorticoid receptors in bovine placentomes during pregnancy, induced parturition and immediately after the expulsion of the fetus. Animals that had retained the fetal membranes were also included in the post partum group. The objectives were to determine the distribution patterns of the receptors in relation to the type of cell, tissue regions, pregnancy status and the discharge of the fetal membranes, to gain new insights into the endocrine regulation of placental growth, maturation and detachment.

\section{Materials and Methods}

\section{Animals}

The uteri of 27 pregnant Holstein-Friesian cows, that is three per month, were collected at the local abattoir. At 30 min after the animals were killed, the animals were eviscerated, the pregnant uteri opened and the crown-rump length of the 27 fetuses was recorded to estimate fetal age: up to $1.5 \mathrm{~cm}, 1$ month; $2.0-3.3 \mathrm{~cm}, 2$ months; $6.8-8.0 \mathrm{~cm}, 3$ months; $15.5-23.0 \mathrm{~cm}, 4$ months; $27.0-31.5 \mathrm{~cm}, 5$ months; $36.0-44.0 \mathrm{~cm}, 6$ months; $48.0-53.0 \mathrm{~cm}, 7$ months; $60.0-66.0$ $\mathrm{cm}, 8$ months and $79.0-81.5 \mathrm{~cm}, 9$ months (Schnorr, 1996). When the embryo was not found macroscopically, the uterine contents of early pregnant animals were examined histologically for embryonic tissues.

Five prepartum cows at 269-282 days after insemination were housed in the Clinic for Bovine Obstetrics and Gynaecology for at least 3 days and received $1 \mathrm{mg}$ cloprostenol (Estrumate ${ }^{\circledR}$, Essex, München) $\mathrm{kg}^{-1}$ body weight. Caesarean sections were performed pre-term, that is $27 \mathrm{~h}$ after prostaglandin administration when no signs of parturition were visible (parturition normally occurs 2-3 days after prostaglandin administration; Aurich and Aurich, 1994). Operations were performed under local anaesthesia with cows standing. Blood samples were collected from the jugular vein immediately before administration of the prostaglandin analogue and at Caesarean section. Plasma was harvested and frozen at $-20^{\circ} \mathrm{C}$ for subsequent measurement of progesterone and total oestrogens performed routinely in the endocrinological laboratory of the Clinic for Bovine Obstetrics and Gynaecology, School of Veterinary Medicine Hannover (Hoffmann et al., 1973a,b).

Five spontaneously calving postpartum cows that discharged the fetal membranes within $12 \mathrm{~h}$ after expulsion of the fetuses and five animals that retained the fetal membranes for more than $12 \mathrm{~h}$ were also involved in the study. These cattle were members of the university dairy herd or from the Clinic for Bovine Obstetrics and Gynaecology.

\section{Tissue sampling and processing}

At the abattoir, at least two randomly selected and comparatively large placentomes, which are part of the allantochorion, were excised from each animal. Macroscopically visible caruncles, the adhering allantochorion and the surrounding segment of the uterine wall were excised from the uterine horn ipsilateral to the corpus luteum in early pregnant cows. A single placentome was collected from the pregnant uterine horn of cows during Caesarean section and from cows immediately post partum. In the latter groups, an elongated effeminator according to Richter, modified by Reisinger (Hauptner, Solingen) was used to obtain the placentomes per vagina. Four to six centrally located crosssections of approximately $5 \mathrm{~mm}$ in thickness were performed on selected tissues. The sections were immersed in $4 \%$ neutral buffered formaldehyde solution (v/v) according to Lillie (Böck, 1989) for $24 \mathrm{~h}$, rinsed in tap water, dehydrated in graded ethanol and acetic acid-n-butyl ester (Riedel-deHaën, Seelze) and embedded in Paraplast Plus ${ }^{\circledR}$ (Sheerwood Medical, St Louis, MO).

\section{Immunohistochemistry}

For receptor histochemical purposes, tissues were cut at $5 \mu \mathrm{m}$ and mounted on to Histo-Bond Superior ${ }^{\circledR}$ adhesive slides (Marienfeld, Bad Mergentheim). Wax was removed from sections using xylene and the sections were rinsed in isopropyl alcohol, hydrated through serial dilutions of ethanol:water and rinsed in PBS (8 g sodium chloride, $1.56 \mathrm{~g}$ $\mathrm{NaH}_{2} \mathrm{PO}_{4}$ (Merck, Darmstadt) to $1000 \mathrm{ml} \mathrm{H}_{2} \mathrm{O}$ ). The action of tissue specific endogenous peroxidases was inhibited by incubating slides in $80 \%$ ethanol with $30 \%$ hydrogen peroxide (v/v) $(197 \mathrm{ml}$ and $3 \mathrm{ml}$, respectively) during hydration. Subsequently, antigen retrieval was carried out by incubating 
the sections in citrate buffer $\left(0.01 \mathrm{~mol}^{-1}, \mathrm{pH} 6.0\right.$; stock solution A: $21 \mathrm{~g}$ citric acid (Merck, Darmstadt) to $1000 \mathrm{ml} \mathrm{H}_{2} \mathrm{O}$; stock solution B: $29.41 \mathrm{~g}$ sodium citrate (Merck, Darmstadt) to $1000 \mathrm{ml} \mathrm{H}$ O; final solution: $9 \mathrm{ml}$ stock solution A plus $41 \mathrm{ml}$ stock solution $\mathrm{B}$ to $500 \mathrm{ml} \mathrm{H} \mathrm{O}$ ) in a microwave oven $(600 \mathrm{~W}$, $1 \times 10 \mathrm{~min}$ and $3 \times 5 \mathrm{~min})$. Sections were encircled with a Dako Pen ${ }^{\circledR}$ (Dako, Hamburg) and blocking was performed by incubating sections in a humidifying chamber for $20 \mathrm{~min}$ with $20 \%$ normal goat serum in PBS. Incubations were performed with two monoclonal antibodies. (i) $\alpha \mathrm{PR} 6\left(12.2 \mu \mathrm{g} \mathrm{m}^{-1}\right.$ in PBS) (Sullivan et al., 1986; gift of D. O. Toft, Mayo Medical School, Rochester, MI), directed against amino acids 113-125 of the chicken receptor (D. O. Toft, personal communication) and crossreacting with the bovine antigen (Hurd et al., 1991). This amino acid sequence is common to forms A and B of the receptor (see Gronemeyer et al., 1987). (ii) Monoclonal antibody HT277 (diluted 1:50 in PBS) directed against amino acids 532-554 of pig oestrogen receptor $\alpha$, domain E (Sierralta and Thole, 1996; Kessels et al., 1998), which are not shared by the oestrogen receptor $\beta$. The two antibodies were used separately for incubation of the sections in a humidifying chamber at room temperature for $1 \mathrm{~h}$ for the immunohistochemical detection of progesterone receptors and oestrogen receptors, respectively. A polyclonal antibody (rabbit, No. PA1-511, Dianova-Immunotech, Hamburg), directed against a 22 amino acid synthetic peptide (aa 346-367, common to receptor forms I and II; see Encio and Detera-Wadleigh, 1997) from the amino terminus of the human glucocorticoid receptor (Cidlowski et al., 1990), diluted 1:300 in PBS, was used for glucocorticoid receptor. Incubation was carried out at room temperature for $1 \mathrm{~h}$. After washing $(3 \times 5 \mathrm{~min})$ in PBS, receptor-antibody complexes were observed using the Vectastain Elite ${ }^{\circledR}$ ABC kit (Vector, Burlingame, CA). The sections were incubated for $30 \mathrm{~min}$ at room temperature with secondary antibodies (goat anti-mouse-IgG or goat antirabbit-IgG, respectively) diluted 1:200 in PBS, rinsed in PBS $(3 \times 5 \mathrm{~min})$ and the avidin-biotinylated peroxidase complex $(\mathrm{ABC})$ reagent was applied for $30 \mathrm{~min}$. The sections were treated with diaminobenzidine tetrahydrochloride (DAB) chromogen, rinsed with PBS $(3 \times 5 \mathrm{~min})$, counterstained with haemalaun according to Mayer (Böck, 1989), rinsed with tap water for $10 \mathrm{~min}$, dehydrated, cleared in xylene and a coverslip was added with Eukitt ${ }^{\circledR}$ (Kindler, Freiburg). For controls, primary antibodies were omitted and a monoclonal antibody directed against $\alpha$-smooth muscle actin (Vector, Burlingame, CA), non-immune mouse IgG (Vector, Burlingame, CA, USA) and a non-immune rabbit serum was used (part of the DAKO EnVisionTM kit, DAKO, Hamburg; gift of I. Walter, Institute of Histology and Embryology, Veterinary University Vienna, Vienna) at a concentration equal to that of the primary antibodies. The specificity of the immunoreactivities was confirmed by the absence of staining in the controls.

\section{Semiquantitative evaluation of immunoreactivities}

Immunoreactivities were evaluated by a single observer at a magnification of $\times 1000$ in three microscopic fields measuring $0.5 \mathrm{~mm}$ in diameter, each in three different tissue locations: (i) placental tissue adjacent to the uterine lumen, the luminal region containing the surface of the placentome, the openings of maternal crypts and basal parts of the fetal villi; (ii) intermediate or central region of the placentome; and (iii) uterine wall orientated tissue regions, the abluminal region of the placentome including the bottom of maternal crypts and top of fetal chorionic villi. The following types of cell were scored separately when they were immunopositive: (a) connective tissue cells of the maternal crypt stroma (progesterone and oestrogen receptors, 100-200 cells per field); (b) endothelial cells and tunica media cells of maternal blood vessels if clearly identifiable by light microscopy (oestrogen and glucocorticoid receptors, 10-20 cells per field); (c) epithelial cells of the maternal crypts (oestrogen and glucocorticoid receptors, 50-200 cells per field during month $1,300-500$ cells during months 2-4, 200-300 cells during months 5-9 and 100-150 cells per field in spontaneously calving animals); (d) connective tissue cells of the vessels of the chorionic villi (glucocorticoid receptors, 10-20 cells per field); and (e) endothelial cells and tunica media cells of the chorionic villi (glucocorticoid receptors, 10-20 cells per field). The intensity of staining of the nuclei was scored as negative $=1$, weak $=2$, intermediate $=4$, or strong $=8$, if these cells showed no brown (that is, blue counterstain), light brown, brown or dark brown staining, respectively. The frequency of the different staining intensities was assessed separately for each type of cell and was evaluated in three randomly selected microscopic fields and then expressed as a percentage of positively stained cells of the respective type of cell. Immunoreactivity of the different types of cell in the three tissue locations described above was expressed using scores (progesterone receptor immunoreactive score, PR-IRS; oestrogen receptor immunoreactive score, ER-IRS; or glucocorticoid receptor immunoreactive score, GR-IRS), which were calculated according to the following procedure modified slightly from Boos et al. (1996).

PR-IRS or ER-IRS or GR-IRS $=1 \times n(\mathrm{SI} 1)+2 \times n(\mathrm{SI} 2)+4$

$$
\times n(\mathrm{SI} 4)+8 \times n(\mathrm{SI} 8)
$$

where $n$ =percentage of cells of a specific type that demonstrated characteristic staining intensities, SI1 = staining intensity negative, SI2 = staining intensity weak, SI 4 = staining intensity intermediate, SI8 = staining intensity strong.

\section{Statistical methods}

Immunoreactive scores were analysed statistically using SAS ${ }^{\circledR}$ software (SAS, 1988) for each type of cell by comparing data from all trimesters of pregnancy and from peripartal groups. Two-way ANOVA was used to evaluate the influence of time (represented by groups of animals) and location (luminal, central or abluminal region of the placentome). Mean values of groups were compared using Student's $t$ test (progesterone receptor data) and the sign rank test was used for analysing oestrogen and glucocorticoid receptor data. Data of plasma progesterone and oestrogen concentrations in animals undergoing Caesarean section were evaluated using a $t$ test for paired data. 


\section{Results}

\section{Progesterone receptors}

Irrespective of pregnancy status, in all placental tissue probes collected, only nuclei of maternal connective tissue cells (fibroblasts and fibrocytes) stained for progesterone receptor (Fig. 1a). All other types of cell of the placentomes did not show immunoreactivity for the progesterone receptor.

Progesterone receptor immunoreactive score of maternal connective tissue cells did not differ significantly between the various locations (luminal, central or abluminal region of the placentome), mean values ranged from 343 to 548, and no definite pattern of staining intensities could be established during gestation (Table 1). However, a significant increase in progesterone receptor immunoreactive score was apparent between the last trimester of pregnancy and induced parturition $(P<0.01)$. A decrease in progesterone receptor immunoreactive score was recorded post partum and was significant $(P<0.05)$ for cows that released the fetal membranes, but not for cows that retained the fetal membranes.

\section{Oestrogen receptors}

Nuclear staining was the prominent feature of immunohistochemistry using HT277 antibody in bovine placentomes (Fig. 1b-d). In fetal chorionic epithelial cells, cytoplasm and plasmalemma also showed weak staining (Fig. 1b,d). Nuclear immunoreactivities occurred in maternal connective tissue cells and in the crypt epithelium. Tunicae mediae of maternal and fetal blood vessels showed weak nuclear staining at the beginning of the second trimester of pregnancy and weak staining was also apparent during induced parturition and post partum.

Oestrogen receptor immunoreactive score of tunicae mediae of fetal blood vessels (Table 1), situated in the luminal region of the placentome reached mean values ranging from 100 to 216. A non-significant increase was recorded during ongoing pregnancy and the highest values occurred during induced parturition $(P<0.05 ; P<0.01$, Table 1$)$. However, decreased oestrogen receptor immunoreactive scores obtained post partum were not significantly different from other values.

Oestrogen receptor immunoreactive scores of maternal stromal fibrocytes (Table 1) did not differ significantly between locations. Mean values ranged from 120 to 346 and showed no definite pattern during pregnancy. Significantly higher oestrogen receptor immunoreactive scores were detected during induced parturition and these values decreased post partum $(P<0.01)$. Differences in immunoreactivities were significant for animals that released the fetal membranes whereas in animals that retained the fetal membranes, the difference was only significant in the central region of the placentome $(P<0.05 ; P<0.01$, Table 1$)$.

Oestrogen receptor immunoreactive score mean values of the tunica media cell nuclei of maternal placental blood vessels (Table 1) did not differ significantly between the various locations. The values ranged from 100 to 232 and increased during pregnancy (significant for the luminal region only; $P<0.01)$ and were highest during induced parturition $(P<0.05 ; P<0.01$, Table 1$)$. A small decrease was recorded post partum, but this result was not significant.

Crypt epithelial cells showed different staining patterns in relation to tissue location (Table 1 ) and mean values ranged from 126 to 487 . During pregnancy, a decrease in oestrogen receptor immunoreactive score was recorded between the first and the second and third trimester; the result was significant for the central region of the placentome $(P<0.05$; $P<0.01$, Table 1). Maternal crypt epithelial oestrogen receptor immunoreactive scores of the second and third trimester were significantly lower than those of animals during induced parturition $(P<0.01)$. A decrease in oestrogen receptor immunoreactive score was recorded post partum and the result was significant for cows that released the fetal membranes $(P<0.01)$. In the luminal region, there was a significant difference between oestrogen receptor immunoreactive scores of animals that retained the fetal membranes and those that released the fetal membranes $(P<0.05)$.

\section{Glucocorticoid receptors}

Glucocoricoid receptors were only detected in nuclei (Fig. 1e,f). Maternal fibroblasts and fibrocytes were essentially devoid of glucocorticoid receptors. Endothelial cells and tunica media cells of maternal and fetal blood vessels showed immunoreactivities for glucocorticoid receptors, as did connective tissue cells of the chorionic villi. Maternal epithelium showed glucocorticoid receptor immunoreactivity which was first observed at the beginning of the second trimester. Glucocorticoid receptors were initially observed in nuclei of maternal epithelial cells covering the fetal aspect of the placentome and of maternal crypt epithelium adjacent to the primary axis of the chorionic villi (Fig. 1e). Towards the end of gestation, maternal crypt epithelial cells adjacent to secondary and tertiary axes of the villi also showed some staining for glucocorticoid receptors. During induced parturition and immediately post partum almost all maternal epithelial cells and some fetal diplocariocytes showed strong staining for glucocorticoid receptors. The latter cells were positive for glucocorticoid receptors when they were in close contact with the maternal stromal compartment (Fig. 1f).

Mean glucocorticoid receptor immunoreactivity score of the fetal connective tissue cells (Table 1) ranged from 155 to 391 and increased significantly from the first to the second $(P<0.01)$ and third $(P<0.05)$ trimester in the luminal region of the placentome. During induced parturition and the post partum period, mean values tended to be lower, but this result was not significant. A similar trend was observed in the abluminal region, whereas in the central region there was no distinct change in glucocorticoid receptor immunoreactivity score.

Glucocorticoid receptor immunoreactivity score of endothelial cells and tunica media cells of fetal blood vessels (Table 1) showed mean values ranging from 149 to 320. 


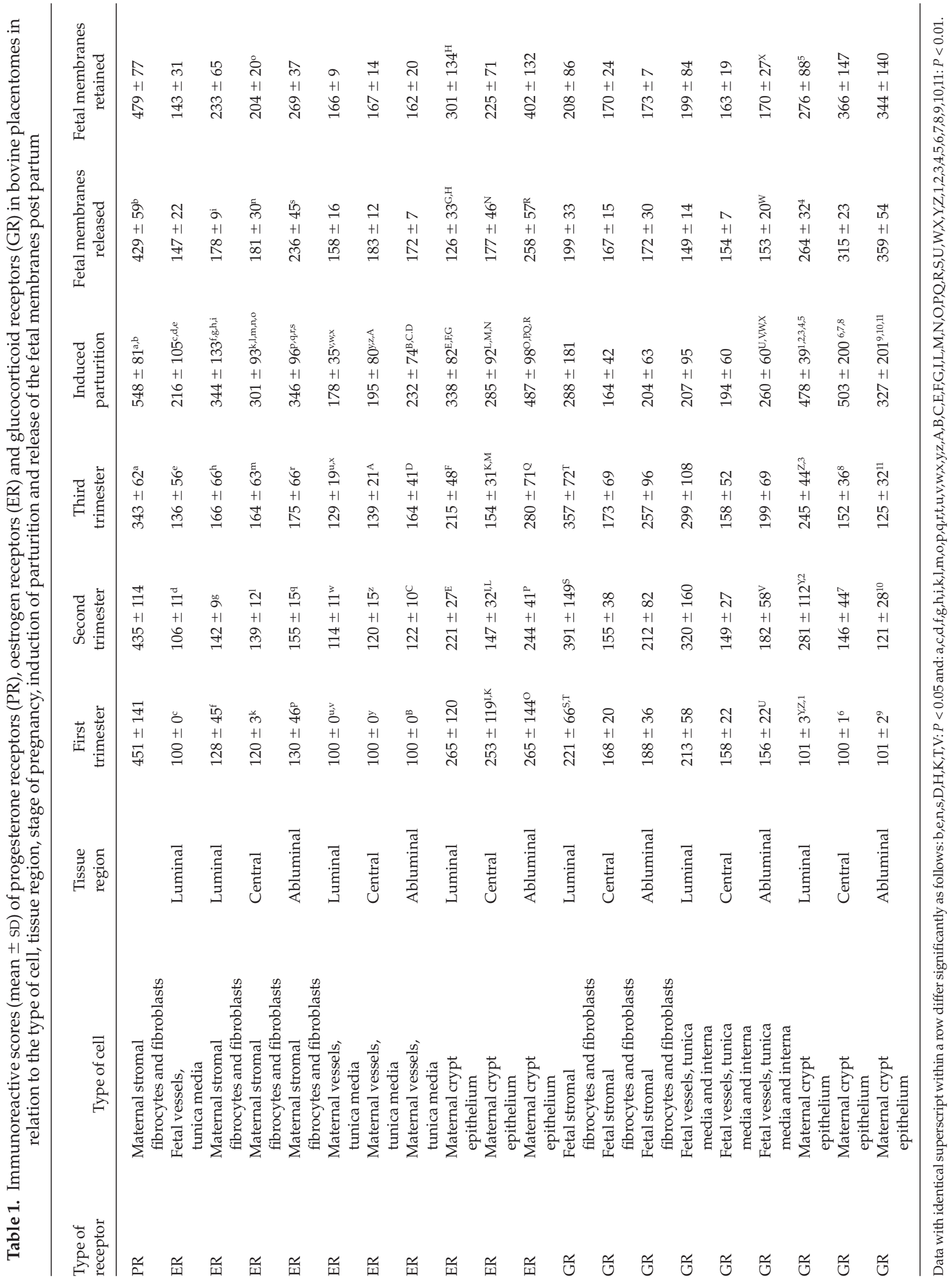



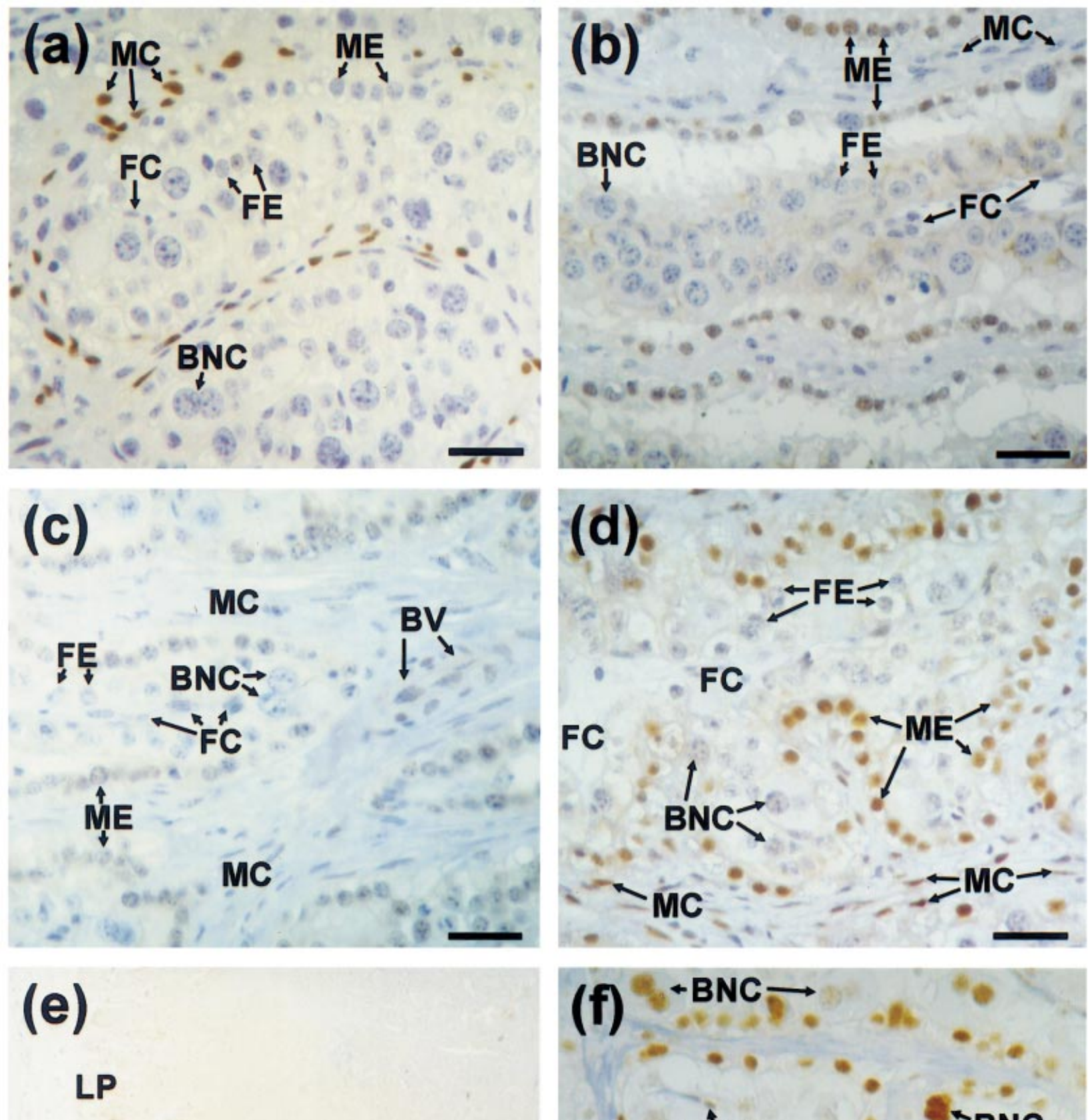

(e)

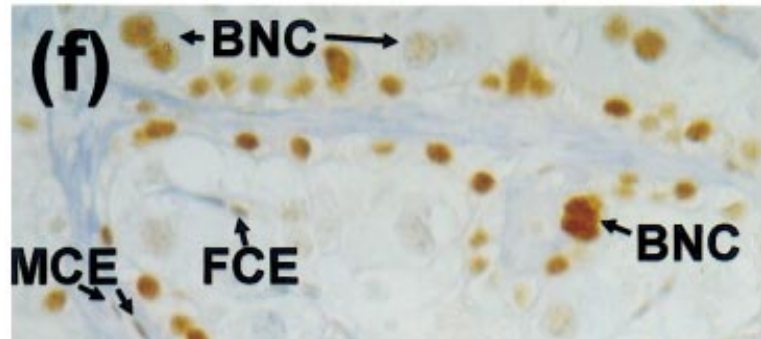

\section{CVPA}

LP

\section{CP}

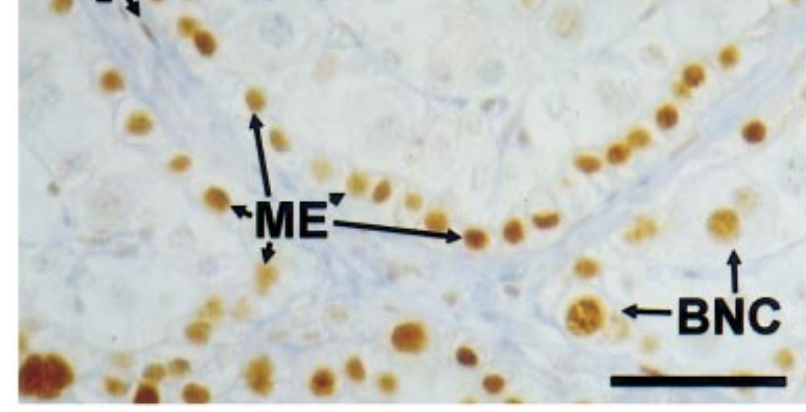

Fig. 1. Immunolocalization (brown staining) of progesterone receptors (a), oestrogen receptors (b-d) and glucocorticoid receptors $(\mathrm{e}, \mathrm{f})$ in bovine placentomes. Tissues were obtained at month 2 (b), month 6 (e) and month 7 (c) of gestation and during Caesarean section at term (month 9$)$ at $27 \mathrm{~h}$ after administration of a progesterone analogue $(\mathrm{a}, \mathrm{d}, \mathrm{f})$. Staining for progesterone receptors and 
Glucocorticoid receptor immunoreactivity score of vessels situated in the abluminal region of the placentome increased significantly from the first $(P<0.01)$ and second $(P<0.05)$ trimester to induced parturition. Tissues obtained post partum showed significantly lower glucocorticoid receptor immunoreactivity scores $(P<0.01)$. Patterns of staining for the luminal and central regions of the placentome were not significant.

Mean glucocorticoid receptor immunoreactivity scores of endothelial cells and tunica media cells of maternal blood vessels (data not shown) ranged from 140 to 219 and did not change significantly during pregnancy or immediately post partum.

However, glucocorticoid receptor immunoreactivity score in maternal crypt epithelial cells showed mean values ranging from 100 to 503 and demonstrated distribution patterns specific to the tissue location and the stage of pregnancy (Table 1). Very low immunoreactivity occurred in the luminal region during the first trimester. However, the second $(P<0.01)$ and third trimester $(P<0.01)$ demonstrated significantly higher values and a further increase was observed during induced parturition $(P<0.01)$. In both post partum groups, glucocorticoid receptor immunoreactivity scores decreased significantly $(P<0.01)$. Glucocorticoid receptor immunoreactivity score of the central and abluminal regions of the placentome showed a different pattern: low values were recorded throughout pregnancy and a significant increase $(P<0.01)$ was evident during induced parturition. Glucocorticoid receptor immunoreactivity scores obtained post partum remained similar in the abluminal region and decreased slightly in the central region, but these results were not significant.

\section{Steroid hormone concentrations}

During the $27 \mathrm{~h}$ period between administration of the prostaglandin analogue and prepartum Caesarean section, progesterone concentrations in the blood decreased significantly $\left(42.6 \pm 12.0\right.$ versus $\left.10.2 \pm 4.4 \mathrm{nmol} \mathrm{l}^{-1} ; P<0.05\right)$ and concentrations of total oestrogens increased significantly (438 \pm 128 versus $\left.529 \pm 109 \mathrm{pg}^{-1} ; P<0.05\right)$.

\section{Discussion}

The results of the present study indicate that bovine placentomes are target organs of various steroid hormones such as progesterone, oestrogens and glucocorticoids. Glucocorticoid receptors were detected at specific sites only towards the end of pregnancy, whereas progesterone receptors and oestrogen receptors were detected throughout pregnancy. This finding is in contrast to an immunohistochemical report by Schoon and Schoon (1991) in which the expression of oestrogen receptors was not observed before day 260 of pregnancy. The present study demonstrates that placental steroid hormone receptors are distributed in patterns specific to the type of cell, tissue location and the stage of pregnancy. This finding implies that different types of cell within the placentome can respond in a distinct manner to identical hormonal stimuli throughout pregnancy. Since nuclear receptors for the ovarian steroids are restricted to specific cells of the maternal compartment of the bovine placentomes, it is suggested that actions of these hormones are mediated by adjacent cells that lack the receptors as well as by the fetus via second messengers in a paracrine fashion. Growth factors and their receptors may play an important role in the mediation of these hormones, as indicated by several studies (Salamonsen, 1992; Seppälä and Rutanen, 1994; O'Malley et al., 1995; Cooke et al., 1998; Rider et al., 1998; Smith, 1998; Wathes et al., 1998).

The role of oestrogen receptors or binding proteins in the fetal chorionic epithelial cells, as demonstrated by cytoplasmic staining and staining of the plasmalemma, remains to be elucidated. Several studies indicate that depending on the antibodies used, steroid hormone receptors may also be detected in the cytoplasm (Boos et al., 1996; Sierralta and Thole, 1996; Kessels et al., 1998). However, this immunoreactivity is usually accompanied by nuclear staining, with the exception of the chorionic epithelium evaluated in the present study (Sierralta and Thole, 1996; Kessels et al., 1998). Thus, the presence of oestrogen receptors in the fetal compartment of the placentome is uncertain. Immunopositive staining of the plasmalemma of fetal chorionic epithelial cells indicates that these cells may be oestrogen sensitive because such binding proteins are reported to be antigenically related to their intracellular counterparts (Watson and Gametchu, 1999). Further work is required in this area.

It is well documented, with several exceptions, that uterine oestrogen receptors and progesterone receptors are generally upregulated by oestrogens and downregulated by progesterone (O'Malley and Tsai, 1992; Xiao and Goff, 1999). However, downregulation of steroid hormone receptors was not confirmed by the present results, since high concentrations of both types of receptor were detected throughout pregnancy. The immunoreactive scores did not decrease as expected, or change significantly during gestation, reflecting the domination of progesterone during pregnancy, that is before initiation of parturition, which is not affected by the increase in conjugated and therefore biologically inactive oestrogens of placental origin (Hoffmann, 1994; Hoffmann et al., 1997). Similar findings in other studies indicate a distribution pattern of the respective endometrial receptors specific to the type of cell, the stage of the oestrous cycle

glucocorticoid receptors is confined to nuclei, whereas weak staining of the cytoplasm (maternal crypt epithelium, d) and some staining of the plasmalemma (chorionic epithelium, b, d) is visible in sections stained for oestrogen receptors. BNC: binuclear trophoblast giant cells; BV: small maternal blood vessel; CP: central part of the placentome; CVPA: chorionic villi, primary axis; FC: fetal connective tissue cells; FCE: fetal capillary endothelium; FE: fetal chorionic epithelial cells; LP: luminal aspect or part of the placentome; MC: maternal connective tissue cells; MCE: maternal capillary endothelium; ME: maternal crypt epithelial cells. Scale bars represent $50 \mu \mathrm{m}(\mathrm{a}-\mathrm{d}, \mathrm{f})$ or $500 \mu \mathrm{m}$ (e), respectively. 
and the tissue location in cattle and other species (Watson et al., 1992; Boos et al., 1996; Tibbetts et al., 1998). At induced parturition, that is $27 \mathrm{~h}$ after administration of the prostaglandin analogue, progesterone and oestrogen receptor immunoreactive scores were significantly higher compared with the preceding stages of pregnancy. This increase in receptor concentration may be the result of decreasing progesterone concentrations and increased concentrations of total oestrogens in maternal blood, reflecting the shift from a long progesterone dominated period to a short oestrogen dominated phase and confirming the interdependence between hormone concentrations in blood and receptor concentrations in target organs.

The presence of oestrogen receptors and glucocorticoid receptors in placental vasculature indicates that the regulation of placental blood flow and angiogenesis may be triggered by the direct action of the respective hormones involved in these events, as detected in clinical and experimental studies (Horwitz and Horwitz, 1982; Tangalakis et al., 1992; Ford, 1995; Brown et al., 1996; BenEzra et al., 1997; Derks et al., 1997).

Glucocorticoids of fetal origin play an important role in the initiation of parturition in domestic ruminants (Hoffmann, 1994; Lye, 1996) and may therefore be used to induce abortion or labour in these species (Aurich and Aurich, 1994; Hoffmann, 1994). As observed in the present study, the placental target cells for the respective hormones during the critical period of placental maturation and labour induction are the maternal crypt epithelial cells and some diplocaryocytes in close contact with the maternal stroma. Maternal crypt epithelial cells demonstrate increasing glucocorticoid receptor immunoreactivities during the second and third trimester of pregnancy, which reached maximum values $27 \mathrm{~h}$ after administration of prostaglandin. The stage-dependent presence of glucocorticoid receptor immunoreactivities is in agreement with the finding that abortion is inducible with glucocorticoids only during the last 3 months of pregnancy in cattle with normal placental function (Aurich and Aurich, 1994). In addition, the role of the interplacental uterine wall in the initiation of labour should be considered as it also shows oestrogen and glucocorticoid receptors and may produce $\mathrm{PGF}_{2 \alpha}$ for luteal regression (Boos, 1998; Kohtes et al., 1998; Fuchs et al., 1999; Janssen et al., 1999).

The pregnancy stage-dependent expression of glucocorticoid receptors in crypt epithelial cells, in maternal diplocaryocytes and in the interplacental uterine wall (Kohtes et al., 1998; Janssen et al., 1999) indicates that the initiation of parturition, that is expulsion of the fetus, and especially the release of the fetal membranes is mediated separately at these sites. This hypothesis is supported by the prepartum decrease in the number of the two types of placental cell mentioned above, which is termed placental maturation (Woicke et al., 1986; Williams et al., 1987; Gross et al., 1991; Al-Sadi et al., 1994). Oestrogens may also play an important role, as crypt epithelial cells have high concentrations of the respective receptors, as demonstrated in the current study.

Compared with placentomes collected $27 \mathrm{~h}$ after prostaglandin administration, placental tissues collected immediately post partum showed significantly lower immunoreactivities for progesterone receptors in maternal connective tissue cells, for oestrogen receptors in maternal crypt epithelial cells and for glucocorticoid receptors in maternal crypt epithelial cells situated centrally in the placenta. However, the differences in immunoreactive scores were not significant in cows that retained the fetal membranes. These results indicate that the shift in receptor immunoreactivities detected in cows that retained the fetal membranes may be the result of altered endocrine events before term, but is not the cause of retention of the fetal membranes. Significantly lower pre-term oestrogen concentrations in maternal blood may play a crucial role (Chew et al., 1979; Lotthammer 1983; Grunert et al., 1989; Fürstenberg et al., 1990; Kankofer et al., 1996; Zhang et al., 1999).

The similarity of the receptor status of placentomes of cows that retained the fetal membranes compared with those collected from pre-term animals $27 \mathrm{~h}$ after prostaglandin administration indicates insufficient placental maturation, which is supported by many morphological and biochemical studies (Björkman and Sollen, 1961; Woicke et al., 1986; Williams et al., 1987; Grunert et al., 1989; Gross et al., 1991; AlSadi et al., 1994; Maj and Kankofer 1997). This hypothesis is also supported by the observation that crypt epithelial cells of animals that retained the fetal membranes show a greater number of such cells undergoing apoptosis compared with those of control cows (Janssen et al., 1999). This observation indicates that apoptotic reduction of the number of epithelial cells reaches a maximum post partum in cows that retain the fetal membranes, whereas in cows that release the fetal membranes this process is already complete.

In summary, the data from the present study support the conclusion that in the bovine placentome, steroid hormone receptors are distributed in a pattern specific to the type of cell, the stage of pregnancy and the tissue location implying a highly specific hormonal regulation. Receptor immunoreactivities reflect hormonal changes during pregnancy and at parturition. Glucocorticoid receptors in maternal crypt epithelial cells mediate initiation of parturition and the release of the fetal membranes. Retention of the fetal membranes is reflected in part by an altered receptor status.

The skillful technical assistance of E. Berger, M. Gähle and N. Eyring and the kind support of W. Meyer are greatly acknowledged. The authors would also like to thank I. Walter, Veterinary University Vienna and D. O. Toft, Mayo Medical School, Rochester for the provision of antibodies.

\section{References}

Agthe O and Kolm HP (1975) Oestrogen and progesterone levels in the blood plasma of cows with normal parturition or with a retained placenta Journal of Reproduction and Fertility 43 163-166

Al-Sadi HI, Majeed AF and Ridha AM (1994) Histopathology of retained bovine fetal membranes Theriogenology 42 273-278

Aurich JE and Aurich C (1994) Geburtseinleitung bei Haustieren Der Praktische Tierarzt 75 742-750

BenEzra D, Griffin BW, Maftzir G, Sharif NA and Clark AF (1997) Topical formulations of novel angiostatic steroids inhibit rabbit corneal neovascularization Investigations in Ophthalmology and Visual Science 38 1954-1962

Björkman N and Sollen P (1961) A morphological study on retentio secundinarum in cattle Acta Veterinaria Scandinavica 2 157-177 
Böck P (1989) Romeis Mikroskopische Technik 17th Edn 697 pp. Urban und Schwarzenberg, München

Boos A (1998) Immunohistochemical assessment of prostaglandin H-synthase in bovine endometrial biopsy samples collected throughout the oestrous cycle Animal Reproduction Science 51 261-273

Boos A, Meyer W, Schwarz R and Grunert E (1996) Immunohistochemical assessment of oestrogen receptor and progesterone receptor distribution in biopsy samples of the bovine endometrium collected throughout the oestrous cycle Animal Reproduction Science 44 11-21

Brown KJ, Maynes SF, Bezos A, Maguire DJ, Ford MD and Parish CR (1996) A novel in vitro assay for human angiogenesis Laboratory Investigations 75 539-555

Chew BP, Erb RE, Zamet CN, Colenbrander VF, Malven PV and D'Amico MF (1979) Variables associated with peripartum traits in dairy cows. V. Hormonal profiles associated with retained fetal membranes Theriogenology 12 245-253

Cidlowski JA, Bellingham DL, Powell-Oliver FE, Luban DB and Sar M (1990) Novel antipeptide antibodies to the human glucocorticoid receptor: recognition of multiple receptor forms in vitro and distinct localization of cytoplasmic and nuclear receptors Molecular Endocrinology 4 1427-1437

Cooke PS, Buchanan DL, Lubahn DB and Cunha GR (1998) Mechanism of estrogen action: lessons from the estrogen receptor- $\alpha$ knockout mouse Biology of Reproduction 59 470-475

Derks JB, Giussani DA, Jenkins SL, Wentworth RA, Visser GH, Padbury JF and Nathanielsz PW (1997) A comparative study of cardiovascular, endocrine and behavioural effects of betamethasone and dexamethasone administration to fetal sheep Journal of Physiology 499 217-226

Elecko J, Kacmarik J, Halagan J and Sevcik A (1982) Progesterone and free estradiol-17-beta-levels in cows at physiological parturition and at parturition with retained placenta Folia Veterinaria 26 29-37

Encio IJ and Detera-Wadleigh SD (1997) PubMed protein data bank, Accession AAB64354

Ford SP (1995) Control of blood flow to the gravid uterus of domestic livestock species Journal of Animal Science 73 1852-1860

Fuchs AR, Rust W and Fields MJ (1999) Accumulation of cyclooxygenase-2 gene transcripts in uterine tissues of pregnant and parturient cows: stimulation by oxytocin Biology of Reproduction 60 341-348

Fürstenberg A, Busch W, Fürstenberg L and Münchow H (1990) Untersuchungen zur Ätiologie der Retentio secundinarum beim Rind Monatshefte Veterinär-Medizin 45 493-496

Gröhn YT, Eicker SW, Ducrocq V and Hertl JA (1998) Effect of diseases on the culling of Holstein dairy cows in New York State Journal of Dairy Science $\mathbf{8 1}$ 966-978

Gronemeyer H, Turcotte B, Quirin-Stricker C et al. (1987) The chicken progesterone receptor: sequence, expression and functional analysis $E M B O$ Journal 20 3985-3994

Gross TS, Williams WF and Russek-Cohen E (1991) Cellular changes in the peripartum bovine fetal placenta related to placental separation Placenta 12 $27-35$

Grunert E (1983) Ätiologie, Pathogenese und Therapie der Nachgeburtsverhaltung beim Rind Wiener tierärztliche Monatsschrift 70 230-235

Grunert E, Ahlers D and Heuwieser W (1989) The role of endogenous estrogens in the maturation process of the bovine placenta Theriogenology 31 1081-1091

Hoffmann B (1994) Gravidität, Geburt und Puerperium. In Veterinärmedizinische Endokrinologie 3rd Edn pp 509-546 Ed. FG Döcke. Fischer, Jena and Stuttgart

Hoffmann B, Kyrein HJ and Ender ML (1973a) An efficient procedure for the determination of progesterone by radioimmunoassay applied to bovine peripheral plasma Hormone Research 4 302-310

Hoffmann B, Schams D, Gimenez T, Ender ML, Herrmann CH and Karg H (1973b) Changes of progesterone, total oestrogens, corticosteroids, prolactin and LH in bovine peripheral plasma around parturition with special reference to the effect of exogenous corticoids and a prolactin inhibitor respectively Acta Endocrinologica 73 385-395

Hoffmann B, Goes de Pinho T and Schuler G (1997) Determination of free and conjugated oestrogens in peripheral blood plasma, feces and urine of cattle throughout pregnancy Experimental and Clinical Endocrinology and Diabetes 105 296-303

Horwitz KB and Horwitz LD (1982) Canine vascular tissues are targets for androgens, estrogens, progestins and glucocorticoids Journal of Clinical Investigation 69 750-758

Hurd C, Nakao M, Eliezer N and Moudgil VK (1991) Immunoanalysis of calf uterine progesterone receptor: modulation of receptor-associated $90 \mathrm{kDa}$ heat-shock protein Molecular and Cellular Biochemistry 105 73-83
Inaba T, Inoue A, Shimizu R, Nakano Y and Mori J (1986) Plasma concentrations of progesterone, estrogens, vitamin $A$ and $\beta$-carotene in cows retaining fetal membranes Japanese Journal of Veterinary Science 48 505-508

Janssen V, Boos A and Kohtes J (1999) Morphological and endocrinological aspects of the bovine uterine wall during pregnancy Reproduction in Domestic Animals 3430

Kankofer M, Zdunczyk S and Hoedemaker M (1996) Contents of triglycerides and cholesterol in bovine placental tissue and in serum as well as plasma concentration of oestrogens in cows with and without retained placental fetal membranes Reproduction in Domestic Animals 31 681-683

Kessels MM, Qualmann B, Thole HH and Sierralta WD (1998) Subcellular localization of estradiol receptor in MCF7 cells studied with nanogoldlabelled antibody fragments European Journal of Histochemistry 42 259-270

Kohtes J, Boos A, Stelljes A and Zerbe H (1998) Immunohistochemical demonstration of glucocorticoid receptors in bovine fetal membranes and uterus during pregnancy Reproduction in Domestic Animals Supplement $\mathbf{5} 76$

Lauer B and Einspanier R (1997) Steroid receptors in reproductive tissue GenBank Database Accession Z86041

Laven RA and Peters AR (1996) Bovine retained placenta: aetiology, pathogenesis and economic loss Veterinary Record 139 465-471

Lotthammer KH (1983) Vergleichende Untersuchungen über den Verlauf der Gehalte an Mineralstoffen, Stoffwechselmetaboliten, Enzymen und Hormonen im Blutserum ante partum bei Milchkühen mit und ohne spätere Retentio secundinarum Deutsche tierärztliche Wochenschrift 90 427-433

Lye SJ (1996) Initiation of parturition Animal Reproduction Science 42 495-503

Maj JG and Kankofer M (1997) Activity of 72-kDa and 92-kDa matrix metalloproteinases in placental tissues of cows with and without retained fetal membranes Placenta 18 683-687

Matton P, Adelakoun V and Dufour JJ (1979) Concentrations de la progestérone, des oestrogènes et du cortisol dans le plasma des vaches ayant donne naissance a des jumeaux ou ayant eu des rétentions placentaires Canadian Journal of Animal Science 59 481-490

Meyer HHD, Mittermeier T and Schams D (1988) Dynamics of oxytocin, estrogen and progestin receptors in the bovine endometrium during the oestrous cycle Acta Endocrinologica 118 96-104

O'Malley BW and Tsai MJ (1992) Molecular pathways of steroid receptor action Biology of Reproduction 46 163-167

O'Malley BW, Schrader WT, Mani S, Smith C, Weigel NL, Conneely OM and Clark JH (1995) An alternative ligand-independent pathway for activation of steroid receptors Recent Progress in Hormone Research 50 333-347

Peter AT and Bosu WTK (1987) Peripartal endocrine changes associated with retained placenta in dairy cows Theriogenology 28 383-394

Rider V, Kimler BF and Justice WM (1998) Progesterone-growth factor interactions in uterine stromal cells Biology of Reproduction 59 464-469

Rosenfeld CS, Yuan X, Manikkam M, Calder MD, Garverick HA and Lubahn DB (1999) Cloning, sequencing and localization of bovine estrogen receptor-beta within the ovarian follicle Biology of Reproduction 60 691-697

Salamonsen LA (1992) Local regulators and the establishment of pregnancy: a review Reproduction, Fertility and Development 4 125-134

SAS (1988) SAS/STAT User's Guide 6th Edn, Statistical Analysis System Institute Inc., Cary, NC

Sauerwein H, Meyer HHD and Möstl E (1989) Low sensitivity to oestrogens in bovine placenta at term Journal of Veterinary Medicine Series A 36 236-240

Schnorr B (1996) Embryologie der Haustiere 3rd Edn 244 pp. Enke, Stuttgart

Schoon HA and Schoon D (1991) Reifungsvorgänge der bovinen Plazentome in der Endphase der Trächtigkeit Proceedings of the 19th Congress of the Deutsche Veterinärmedizinische Gesellschaft, Bad Nauheim, pp 67-80

Schuler G, Wirth C, Klisch K, Pfarrer C, Leiser R and Hoffmann B (1999) Immunolocalization of progesterone receptors in bovine placentomes throughout mid and late gestation and at parturition Biology of Reproduction 61 797-801

Seppälä M and Rutanen EM (1994) Paracrine interactions in endometrial function. In Molecular Biology of the Female Reproductive System pp 379-393 Ed. JK Findlay. Academic Press, San Diego

Sierralta WD and Thole HH (1996) Retrieval of estradiol receptor in paraffin sections of resting porcine uteri by microwave treatment. Immunostaining patterns obtained with different primary antibodies Histochemistry and Cell Biology 105 357-363

Smith CL (1998) Cross-talk between peptide growth factor and estrogen receptor signalling pathways Biology of Reproduction 58 627-632

Sullivan WP, Beito TG, Proper J, Krco CJ and Toft DO (1986) Preparation of monoclonal antibodies to the avian progesterone receptor Endocrinology 119 $1549-1557$ 
Tangalakis K, Lumbers ER, Moritz KM, Towstoless MK and Wintour EM (1992) Effect of cortisol on blood pressure and vascular reactivity in the ovine fetus Experimental Physiology 77 709-717

Thorburn GD and Liggins GC (1994) Role of the fetal pituitary-adrenal axis and placenta in the initiation of parturition. In Marshall's Physiology of Reproduction 4th Edn pp 1003-1028 Ed. GE Lamming. Chapman and Hall, London

Tibbetts TA, Mendoza-Meneses M, O'Malley BW and Conneely OM (1998) Mutual and intercompartmental regulation of estrogen receptor and progesterone receptor expression in the mouse uterus Biology of Reproduction 59 1143-1152

Vesanen M, Isomaa V, Alanko M and Vikho R (1991) Bovine uterine, cervical and ovarian estrogen and progesterone receptor concentrations Animal Reproduction Science 26 61-71

Walther N, Lioutas C, Tillmann G and Ivell R (1999) Cloning of the bovine estrogen receptor beta: expression of novel deleted isoforms in reproductive tissues Molecular and Cellular Endocrinology 152 37-45

Wathes DC, Reynolds TS, Robinson RS and Stevenson KR (1998) Role of the insulin-like growth factor system in uterine function and placental development in ruminants Journal of Dairy Science 81 1778-1789
Watson CS and Gametchu B (1999) Membrane-initiated steroid actions and the proteins that mediate them Proceedings of the Society for Experimental Biology and Medicine 220 9-19

Watson ED, Skolnik SB and Zanecosky HG (1992) Progesterone and estrogen receptor distribution in the endometrium of the mare Theriogenology 38 575-580

Williams WF, Margolis MJ, Manspeaker J, Douglass LW and Davidson JP (1987) Peripartum changes in the bovine placenta related to fetal membrane retention Theriogenology 28 213-223

Woicke J, Schoon HA, Heuwieser W, Schulz LC and Grunert E (1986) Morphologische und funktionelle Aspekte plazentarer Reifungsmechanismen beim Rind Journal of Veterinary Medicine Series A 33 660-667

Xiao CW and Goff AK (1999) Hormonal regulation of oestrogen and progesterone receptors in cultured bovine endometrial cells Journal of Reproduction and Fertility 115 101-109

Zhang WC, Nakao T, Moriyoshi M, Nakada K, Ohtaki T, Ribadu AY and Tanaka Y (1999) The relationship between plasma oestrone sulphate concentrations in pregnant dairy cattle and calf birth weight, calf viability, placental weight and placental expulsion Animal Reproduction Science 54 169-178 